PF 2020 (75/1): 399-415 https://doi.org/10.32798/pf.670

\author{
KAMILA POTOCKA-PIROSZ \\ Instytut Polonistyki Stosowanej \\ Uniwersytet Warszawski, Warszawa \\ e-mail: k.potocka@uw.edu.pl \\ ORCID 0000-0003-1939-8066
}

\title{
O DIAGNOZIE. ANALIZA SKŁADNIOWO-SEMANTYCZNA
}

\section{ON DIAGNOSIS. SEMANTIC-SYNTACTIC ANALYSIS}

\begin{abstract}
The aim of the analysis is to present a valence characteristics of the noun diagnoza (diagnosis). I start with reviewing several dictionary definitions, in order to find out how many meanings of diagnoza should be recognized. In what follows, I describe the deep structure of diagnoza, based on the analysis of the examples from the selected dictionaries and The Polish Valency Dictionary (Walenty). The next step is to characterize morphological and semantic criteria for the positions opened by this noun. And finally, I discuss some problems with interpreting surface realizations of this noun. The analysis is based on the evidence from The National Corpus of Polish.
\end{abstract}

KEYWORDS: noun, valency, semantics

SŁOWA KLUCZOWE: rzeczownik, walencja, semantyka

\section{Wstęp}

Wybór leksemu diagnoza do analizy składniowo-semantycznej był podyktowany faktem, że jest on różnie definiowany w słownikach i różnie jest stosowany przez użytkowników języka. Zainteresowało mnie, ile znaczeń leksemu diagnoza powinno się wyróżniać ze względu na właściwości składniowe i semantyczne tego wyrażenia. 
Opierając się na podanych przez Danutę Buttlerową (1976, s. 20) trzech poziomach badania walencji ${ }^{1}$, spróbuję wskazać liczbę obligatoryjnych pozycji, które pojawiają się przy omawianym rzeczowniku oraz morfologiczne wymogi i semantyczne ograniczenia nakładane na te pozycje. Do analizy wykorzystałam głównie przykłady z NKJP${ }^{2}$, ze słowników języka polskiego i elektronicznego słownika walencyjnego Walenty ${ }^{3}$. W niektórych miejscach proponuję własne przykłady i przykłady $z$ internetu.

\section{Słownikowy rekonesans}

Diagnoza pochodzi z języka greckiego i oznacza rozpoznanie ${ }^{4}$ (diágnōsis). W języku francuskim był to termin medyczny (diagnose) i w takiej funkcji został zapożyczony do polszczyzny (Etymologiczny słownik języka polskiego, 2000, s. 271). Pierwszym polskim słownikiem, w którym odnotowano definicję rzeczownika diagnoza, był Słownik języka polskiego pod red. Witolda Doroszewskiego (SJPDor). Poniżej przedstawiam definicje i przykłady użycia tego leksemu z SJPDor oraz trzech słowników z XXI w. - Innego słownika języka polskiego (ISJP), Uniwersalnego słownika języka polskiego (USJP), Wielkiego słownika języka polskiego (WSJP).

SJPDor wyodrębnia dwa znaczenia rzeczownika diagnoza:

1a/ Rozpoznanie choroby.

W czasie swojego długiego pobytu w szpitalu otrzaskał się z terminologią medyczną i z niezachwianą pewnością sam stawiał diagnozy.

1b/ przen.

Savany wysłany po zjeździe w Tylży do Petersburga dla zbadania tamtejszego terenu, przesłał Napoleonowi raporta [raporty], zawierające ciekawą diagnozę położenia stolicy Rosji.

2/ bot., zool. Naukowy opis cech charakteryzujących jednostki systematyczne roślin i zwierząt.

Systematyk w swojej pracy opiera się na diagnozach gatunków i na tej podstawie buduje system stwarzając jednostki coraz to wyższego rzędu (rodzaje, rodziny, rzędy itd.).

ISJP również przytacza dwie definicje:

1 Wg Danuty Buttler (1976) są to poziomy: 1) strukturalny - tu badana jest liczba pozycji i ich obligatoryjność 2) kategorialny - tu sprawdzana jest zwartość morfologiczna pozycji; 3) selekcyjno-semantyczny - tu brane są pod uwagę klasy znaczeniowe wyrazów w danych pozycjach.

2 Na podstawie materiału z NKJP, http://nkjp.pl/ [dostęp: 13.07.2020 r.].

3 Słownik walencyjny Walenty, http://walenty.ipipan.waw.pl/ [dostęp: 20.07.2020].

$4 \quad$ Słownik wyrazów bliskoznacznych (Ludwiczak, Piskadłowa, Tarka-Huczek, 1998, s. 341) podaje rozpoznanie (obok kwalifikacji i oceny stanu) jako wyraz bliskoznaczny leksemu diagnoza. 
1/ Diagnoza to rozpoznanie rodzaju choroby.

Komputer ułatwia lekarzowi postawienie bezbłędnej diagnozy.

2/ Diagnozą możemy nazwać czyjąś opinię na jakiś temat lub ocenę czegoś.

Diagnoza ekologów dotycząca przyszłości Ziemi może przerazić każdego jej mieszkańca.

Także w USJP wyróżniono dwa znaczenia diagnozy, dodatkowo przy znaczeniu medycznym osobno wskazano terminy związane z dziedziną psychologii i socjologii:

1/ med. Rozpoznanie choroby na podstawie jej objawów, badania chorego, wywiadu lekarskiego i badań laboratoryjnych.

$\diamond$ psych. Rozpoznanie za pomocą technik i metod psychologicznych cech osobowości, właściwości psychicznych, odchyleń od normy w zakresie intelektualnym i emocjonalnym.

$\checkmark$ spot. Określenie cech współcześnie zachodzących zjawisk społecznych na podstawie przeprowadzonych badań empirycznych i ich analizy przygotowana na potrzeby praktyki społecznej i politycznej.

2/ książk. przen. Ocena wydana na podstawie analizy.

Przemówienie zawierało bardzo celną diagnozę sytuacji społecznej i gospodarczej.

$\mathrm{WSJP}^{5}$ zaś podaje trzy znaczenia tego leksemu związane z różnymi dziedzinami. W każdym znaczeniu dodatkowo wyszczególniono dwa podtypy - a) czynność i b) rezultat czynności:

1a/ Stwierdzanie na podstawie badania, na jaką chorobę cierpi człowiek lub zwierzę.

Jest jeszcze potrzeba powstania w powiecie ośrodka wczesnej interwencji, który prowadzi diagnozę i rehabilitację niepełnosprawnych umysłowo dzieci [...].

1b/ Opinia o tym, na jaką chorobę cierpi człowiek lub zwierzę, sformułowana na podstawie badań.

Wiesz, że w Krzemowej Dolinie w Kalifornii zanotowano ostatnio znaczny wzrost liczby diagnoz syndromu Aspergera oraz autyzmu wśród dzieci?

2a/ Stwierdzanie na podstawie badania, jaki jest stan kogoś lub czegoś.

Zaczęliśmy od diagnozy sytuacji szpitala, która nie wypadła najlepiej.

5 Dostęp online https://wsjp.pl/ [13.07.2020]. 
2b/ Opinia na temat tego, jaki jest stan kogoś lub czegoś, sformułowana na podstawie badań.

Dziś usłyszałem diagnozę, że mam pęknięty kolektor wydechowy. Byłem u kilku mechaników i każdy ma swoją opinię, co z tym fantem zrobić.

3a/ biol. Rozpoznawanie gatunków roślin lub zwierząt.

Przy diagnozie taksonu podaje się kształt okrywy i jej zakończeń, długość i szerokość okrywy, liczbę prążków, punktów lub areol w jednostce długości tzn. w 10 (m., kształt szczeliny i jej zakończeń, kształt pola podłużnego i środkowego (jest to przestrzeń na okrywie, którą tworzą zakończenia prążków).

3b/ biol. Opis cech charakteryzujących dany rodzaj lub gatunek rośliny lub zwierzęcia.

Diagnoza gatunku G. musceli jest następująca: kręgosłup złożony z 45-51 kręgów, płetwa grzbietowa zaczyna się w środku ciała, płetwa odbytowa zaczyna się o 4-8 kręgów za ostatnim promieniem płetwy grzbietowej, płetwy brzuszne położone są pod początkiem płetwy grzbietowej.

Do przedstawionych znaczeń jeszcze powrócę dalej. Tymczasem osobnego skomentowania wymaga propozycja dziewiętnastu ${ }^{6}$ schematów diagnozy ze słownika walencji Walenty. Omówię je na podstawie podawanych w tym słowniku przykładów, podejmując jednocześnie próbę uporządkowania schematów $\mathrm{z}$ nich wynikających ${ }^{7}$.

a. Przykłady (1)-(5) zawierające wyrażenia na temat / w kwestii / w sprawie / w dziedzinie/ w zakresie realizują schemat: (CZYJAŚ) diagnoza (dotycząca) CZEGOŚ8:

(1) Muszę przyznać, że pan prezes Jagiełło w wielu punktach swojej diagnozy na temat sytuacji w Mechanicznych ma rację.

(2) Ja, Brave, Agar i kilka innych osób jak czytam podało tą samą diagnozę w kwestii merytoryki i sposobu prowadzenia przez ciebie dyskusji

6 Przykładów jest więcej niż schematów wyszczególnionych w Walentym, ponieważ autorzy słownika łączą niektóre przykłady w warianty jednego schematu, np.: diagnoza z czegoś, diagnoza tego + zdanie, diagnoza tego, że.

Większość przykładów w słowniku Walenty pochodzi z NKJP, sporadycznie są uzupełniane przykładami z Internetu lub własnymi przykładami autorów słownika. Przykłady uporządkowałam według podobieństwa schematów. W przykładach zostały wyróżnione realizacje schematów leksemu diagnoza.

8 W słowniku Walenty nie odnotowano tego użycia, spotykanego dość często, por.: Sens opóźnień polega na tym, że między diagnoza dotyczaca stanu gospodarki a przygotowaniem określonych środków polityki ekonomicznej uplywa tak wiele czasu, że w momencie, w którym środki (narzędzia) te sa gotowe, układ gospodarki na tyle się zmienit, iż narzędzia te sa już nieskuteczne. (NKJP, Stanisław Owsiak, Finanse publiczne, 1998). 
(3) Czekam teraz na diagnozę w sprawie nerki.

(4) Wydaje Ci się... diagnoza w dziedzinie paranoi jest bardzo łatwa - polega na konfrontacji z rzeczywistością.

(5) Omawiane wyniki badań dotyczące takich zagadnień, jak prognozy zatrudnienia, listy poszukiwanych zawodów, analiza potencjału rynku pozwoli postawić diagnozę w zakresie oferty edukacyjnej oraz mobilności Wielkopolan.

b. Przykład (6) zawierający wyrażenie z zakresu oraz przykłady (7)-(10) realizujące odpowiednio schematy: diagnoza W CZYMŚ, diagnoza O CZYMŚ, diagnoza O TYM + że_/ pytanie zależne - należałoby uznać za niepoprawne. W słowniku walencyjnym Walenty taka realizacja jest również oznaczona jako wątpliwa ${ }^{9}$.

(6) Oprócz diagnozy z zakresu swojej specjalizacji ocenią, czy ich pacjenci mogą uczestniczyć w zajęciach $\mathrm{z}$ hipoterapii, które w tym dniu również nieodpłatnie będą prowadzone w Klubie Jeździecki „Bór” w Toporzysku.

(7) Sumka ta, niby niewielka, pozwoliłaby przecież na przeprowadzenie przeszło 70 koronarografii, które stanowią obecnie najskuteczniejszą metodę umożliwiającą postawienie właściwej diagnozy w chorobie wieńcowej.

(8) Lekarska diagnoza o głębokiej depresji i konieczności kuracji nikogo nie zdziwiła.

(9) Diagnoza o tym, że jesteśmy skazani do końca życia na nieuleczalną chorobę, jest ogromnym ciosem dla chorych.

(10) Diagnoza o złamaniu i o tym, ile potrwa powrót do zdrowia piłkarza, została podana do wiadomości publicznej dopiero tydzień po meczu.

c. Przykłady (11)-(17) realizujące schematy: diagnoza CO DO CZEGOŚ, diagnoza CO DO TEGO + że_/ pytanie zależne, diagnoza (TEGO) + że_/ pytanie zależne / cytat - można uznać za realizacje jednego schematu: (CZYJAŚ) diagno$z a$ (CZEGOŚ) (̇̇e_/ pytanie zależne / cytat):

(11) Nie jest możliwe po samym opisie wystawić trafną diagnozę co do tej kontuzji i co do tego, czy to rzeczywiście jest pęknięcie kości, czy nie.

(12) Diagnoza co do tego, że mam prawie całkowity ubytek słuchu, została postawiona w trakcie trwania ubezpieczenia, to że może to być usunięte jedynie operacyjnie - również.

(13) W środę będzie dalsza diagnoza, ile zaworów poszło i czy również tłoki są do wymiany.

(14) Czy rzecznik ma pełną świadomość i pełną diagnozę tego, ile dzieci żyje w skrajnym ubóstwie?

9 Być może zdania (6)-(7) to przykłady użyć z socjolektu medyków. 
(15) I tylko tam, gdzie jest mowa o rolnictwie, na stronie 52, znajdujemy sformułowanie, które jest diagnozą tego, że przepaść cywilizacyjna między miastami i terenami wiejskimi pogłębia się.

(16) Tu jednak wraca moja diagnoza, że problemem światowej gospodarki jest dziś nie inflacja, ale deflacja.

(17) Wszystko zmieniła wizyta u lekarza i diagnoza: mięśniaki na macicy.

d. Przykłady (18)-(20) zawierają informację wskazującą na podstawę diagnozy użyte jest wprost wyrażenie na podstawie (CZEGOŚ) lub schemat: diagnoza Z CZE$\mathrm{GOS}^{10}$ :

(18) Pierwsza diagnoza na podstawie objawów mogła zwalić z nóg, brzmiała jak wyrok śmierci - guz mózgu.

(19) Pacjent nie dał wiary diagnozie na podstawie samych badań tętna, że ma raka.

(20) Diagnozą z tęczówki oczu zajmuje się irydologia.

e. W przykładzie (21) wyrażenie za pomoca (czegoś) wskazuje, że do diagnozy wykorzystano narzędzie:

(21) W efekcie też diagnoza za pomocą różnych narzędzi nie mogła wykazywać zgodności.

f. W zdaniach (22)-(24) wyrażenie ze strony wskazuje na agensa (autora) diagnozy. Poprawność tych zdań budzi jednak moje zastrzeżenia. W tych przykładach pojawia się również pozycja dla obiektu diagnozy realizowana według schematów opisanych w punkcie b. i c. Schematy z tych zdań można zatem byłoby sprowadzić do jednego ogólnego schematu CZYJAŚ diagnoza CZEGOŚ (że_/ pytanie zależne / cytat):

(22) Na początku wymagana jest diagnoza ze strony specjalisty, potem rodzice edukują się w temacie zespołu ADHD.

(23) Powaliła mnie diagnoza ze strony specjalisty co do stanu mojego zdrowia i tego, jak od dzisiaj wyglądać będzie moje życie.

(24) Powaliła mnie diagnoza ze strony specjalisty co do stanu mojego zdrowia i tego, że od teraz muszę się bardzo oszczędzać i zrezygnować z wyczynowego uprawiania sportu.

g. Przykłady (25)-(26) realizując schemat (CZYJAŚ) diagnoza DLA KOGOŚ (że_/ pytanie zależne / cytat), być może wskazują na pozycję odbiorcy diagnozy ${ }^{11}$.

10 Konstrukcja diagnoza Z CZEGOŚ pojawia się w określonych tekstach dotyczących diagnoz paramedycznych. Moim zdaniem stanowi skrót wyrażenia diagnoza na podstawie czegoś.

11 Być może w przykładzie (25) przyimek dla związany jest z czasownikiem organizować, a w przykładzie (26), dokonano pewnego skrótu: Moja diagnoza dla księdza brzmi (...) $\rightarrow$ Mam dla księdza diagnozę, która brzmi (...). 
(25) Akcję bezpłatnych diagnoz logopedycznych dla 6- i 7-latków organizuje Szkoła Podstawowa nr 3 przy ul. Topolowej 22.

(26) Moja diagnoza dla Księdza brzmi: urok osobisty.

h. W przykładzie (27) pojawia się wyrażenie JAKOBY, które poza wprowadzeniem treści diagnozy pokazuje stosunek nadawcy komunikatu do prezentowanej treści czyjejś diagnozy. Przykład realizuje schemat CZYJAŚ diagnoza JAKOBY_:

(27) Natomiast Twoja diagnoza jakoby cała sprawa wynikała z powodu „tej drugiej” jest IMHO błędna.

Wśród przykładów wyróżnionych w słowniku Walenty znalazły się realizacje: nieprawidłowe (przykłady w punkcie b.), eliptyczne (przykład (20), (26)), otwierające miejsca dla (być może) dodatkowej pozycji narzędzia (przykład (21)). Pozostałe realizacje można, jak sądzę, sprowadzić do struktury:

CZYJAŚ (X-a) diagnoza CZEGOŚ (stanu Y-a / K) (̇̇e) p [za pomocą f / na podstawie $\mathrm{g}]$

gdzie: $\mathrm{X}$ - agens, $\mathrm{Y}$ - obiekt, $\mathrm{K}$-zdarzenie, $\mathrm{p}$ - treść diagnozy, f - narzędzie, g środek czynności

Sądzę, że blokowanie w strukturze powierzchniowej realizacji pozycji dla narzędzia i środka czynności wskazuje na funkcjonowanie leksemu diagno$z a$ jako nazwy czynności (synonim: diagnozowanie) i jako nazwy rezultatu diagnozowania ${ }^{12}$.

\section{Właściwości semantyczno-składniowe}

Celem dalszych rozważań będzie charakterystyka pozycji wyznaczonych zarówno przez nazwę przedmiotową (CZYJAŚ (X-a) diagnoza CZEGOŚ (stanu Y-a / K) (ie) p [na podstawie g]), jak i przez nazwę czynności (CZYJAŚ (X-a) diagno$z a$ CZEGOŚ (stanu Y-a / K) (íe) p [za pomocą f]).

\section{diagnoza CZYJAŚ (X-a)}

Pozycja CZYJAŚ jest przewidziana dla nazwy agensa, będącego autorem diagnozy. Diagnozę mogą stawiać wyłącznie ludzie (por. *Pies postawił diagnozę dotyczącą mojego stanu zdrowia.) - są to pojedyncze osoby (np. pedagog) lub grupy osób (np. pomysłodawcy z MSWiA), mogą być wskazane konkretnie (z referencją, np. biegły rewident dr Piotr Rojek), por.:

12 Tym samym uważam, że zasadne jest odróżnienie przez WSJP diagnozy jako czynności i jako rezultatu czynności. Do wyodrębnianych przez słowniki znaczeń, oznaczanych kwalifikatorami biol., med., psych., społ., przen. powrócę w podsumowaniu. 
(28) Moja diagnoza jest inna. Przyszłość relacji między kobietami i mężczyznami zależeć będzie od wychowania. (NKJP, Jarosław Makowski, Kobiety uczą kościół, 2007)

(29) Belferska diagnoza była zatem jasna: skoro tyle wagaruje i na dodatek wcale się nie uczy,

(30) Jaka jest pana diagnoza? (NKJP, Andrzej Sapkowski, Historia i fantastyka, 2005)

(31) Podobne problemy ma wiele zdolnych dzieci, dla których zła diagnoza pedagoga lub rezygnacja z wizyty w poradni, oznacza horror w szkolnej ławce. (NKJP, Aldona Minorczyk-Cichy, Błędna diagnoza, 2002)

(32) Niestety, nie budzi optymizmu diagnoza biegłego rewidenta dr Piotra Rojka, który w raporcie dla marszałka stwierdził (...). (NKJP, Grażyna Kuźnik, Fundusz kontra fundusz, 2006)

(33) Sama diagnoza pomysłodawców z MSWiA jest jednak arcytrafna: na ewentualny atak terrorystyczny nie jesteśmy dobrze przygotowani i coś trzeba z tym zrobić, zanim nie będzie za późno, (NKJP, Sławomir Kmiecik, Superminister od terroru, 2004)

Czasami w pozycji przeznaczonej dla agensa pojawiają się nazwy urządzeń, por.

(34) Komputer dokonuje diagnozy na podstawie skanu mózgu pacjenta. Ma on odpowiednio zbudowaną bazę danych, w skład której wchodzą obrazy mózgu osób zdrowych oraz chorych w różnych stadiach. (NKJP, Michał Chudziński, Komputer lepiej zdiagnozuje Alzheimera, 2008)

Wydaje się jednak, że jest to pewien skrót. Dane do komputera wprowadził człowiek i to on ów komputer obsługuje. Maszyna zatem stanowi jedynie narzędzie, które wspomaga człowieka w procesie diagnozowania.

Gdy pozycja agensa-autora diagnozy jest realizowana przez rzeczownik, ma on formę dopełniacza (np. [diagnoza] pana, pedagoga). Gdy wskazanie na agensa wyrażone jest przez zaimek lub przymiotnik dzierżawczy (np. moja [diagnoza], belferska [diagnoza]), uzupełnienie jest realizowane w składni zgody.

\section{diagnoza CZEGOŚ (stanu Y-a / K)}

Pozycja CZEGOŚ przewidziana jest dla obiektu diagnozowania (tematu diagnozy). Prawostronnie, obok diagnozy występuje: /a/ nazwa diagnozowanego zdarzenia (np. diagnoza mojej sytuacji) lub /b/ nazwa diagnozowanego obiektu (np. diagnoza katalizatora). Drugie uzupełnienie stanowi wyrażenia eliptyczne: diagnoza stanu X-a.

Pozycja obiektu-tematu wyrażana jest najczęściej rzeczownikiem (lub frazą rzeczownikową) w dopełniaczu, por.:

(35) Niestety. Ponura diagnoza mojej sytuacji. Postaci dość dziwacznej. (NKJP, Tadeusz Zimecki, Ja, Franek..., 2001) 
(36) Była to diagnoza moralnego niepokoju. (NKJP, Jarosław Flis, Kaczyński wraca do starych wojen, 2008)

(37) Kompleksowa diagnoza katalizatora nie jest możliwa we własnym zakresie, musimy skorzystać z pomocy wykwalifikowanych mechaników. (NKJP, Marcin Domaradzki, Warto sprawdzić katalizator, 2011)

(38) Jednym z głównych naszych zadań jest wczesna diagnoza dziecka dysfunkcyjnego, a do tego odpowiedni program jest niezbędny. (NKJP, Milena Kochanowska, Aś ma dysleksję a Ania oczy niebieskie, 2005)

(39) Szybka diagnoza pacjentów wymaga zakupu nowoczesnego sprzętu. (NKJP, Zofia Sitarz, Miliony na sprzęt, remonty i termomodernizację, 2005)

W przykładach (37)-(39) mamy do czynienia z elipsą w pozycji obiektu-tematu: diagnoza stanu Y-a $\rightarrow$ diagnoza Y-a. (zob. diagnoza katalizatora $\rightarrow$ diagnoza stanu katalizatora, diagnoza dziecka $\rightarrow$ diagnoza stanu zdrowia dziecka, diagnoza pacjentów $\rightarrow$ diagnoza stanu zdrowia pacjentów).

Ponadto pozycja obiektu-tematu diagnozy może być realizowana przez pytanie zależne, por.:

(40) W każdym z nich zbadanie zawartości obu izotopów 14C i 12C dawało niezbite dowody na postawienie diagnozy, ile lat liczy sobie dany materiał. (NKJP, Antoni Kapelański, Wielki Koneser, 2006)

A także wprowadzana przez wyrażenia $w$ sprawie / kwestii / zakresie / dziedzinie, por.:

(41) Przecież na diagnozę w sprawie kraksy Zientarskiego tez trzeba było czekać. (NKJP, Grzegorz Rossa, Tego też z wielka pompa pochować $w$ alei zasłużonych, 2008)

Pozycje dla nazwy agensa i obiektu-tematu rzadko realizowane są jednocześnie, gdyż poprawność tak zbudowanych zdań (gdy obie te pozycje są wyrażone rzeczownikiem w dopełniaczu) budzi zastrzeżenia, , por.:

(42) ?Diagnoza lekarza stanu zdrowia Jana była słuszna.

(43) ${ }^{\star}$ Diagnoza mechanika katalizatora nie była możliwa.

Gdy realizowana jest tylko jedna $\mathrm{z}$ tych pozycji i nie jest znany pełny kontekst, wówczas również pojawia się problem: nazwa w dopełniaczu może być interpretowana jako agens bądź obiekt czynności diagnozowania. Na przykład w zdaniu Diagnoza Jana była dobra / słuszna / zła. - nie wiadomo, czy to Jan sformułował diagnoze, czy też dotyczyła jego stanu. Jednoczesne wskazanie agensa i obiektu diagnozy jest możliwe i poprawne, o ile w pozycji przeznaczonej dla agensa wystąpi przymiotnik, zaimek dzierżawczy albo pozycja obiektu-tematu zostanie 
wprowadzona przez wyrażenia: dotyczaca lub na temat / w sprawie / kwestii / zakresie / dziedzinie, por.:

(44) Twoja diagnoza stanu zdrowia Jana była słuszna.

(45) Diagnoza lekarza dotycząca / na temat stanu zdrowia Jana była słuszna.

\section{$\operatorname{diagnoza}(\dot{\mathbf{z} e}) \mathbf{p}$}

Pozycja (że) p przewidziana jest dla treści diagnozy. Zarówno diagnoza-czynność i diagnoza-rezultat czynności są operacjami mentalnymi. Uważam, że w obu przypadkach treść diagnozy jest obligatoryjna (chociaż nie zawsze realizowana powierzchniowo), bowiem na pytanie o treść diagnozy nadawca nie może odpowiedzieć „nie wiem”" ${ }^{13}$. W tej pozycji może pojawić się zdanie wprowadzone przez że albo cytat, por.:

(46) Początkowo była wyraźna diagnoza, że mam uszkodzoną śledzionę od uderzenia. (źródło NKJP, APP, Wolny ambasador, 2006)

(47) Taka była diagnoza: $w$ mojej przyjaciółce ciągle tkwi mała nieszczęśliwa dziewczynka, z którą teraz, po latach, trzeba wreszcie zrobić porządek.(NKJP,Anna Bojarska, Maria Bojarska, bez tytułu, 1996)

W pozycji tej może wystąpić także fraza rzeczownikowa w dopełniaczu:

(48) Tym samym potwierdza się diagnoza ostrego zapalenia krtani i tchawicy z epizodami spazmatycznego kaszlu. (NKJP, Marek Twaróg, Agata Pustułka, Ojciec Święty w szpitalu, 2005)

Pozycje dla nazwy agensa-autora diagnozy, jej obiektu oraz treści są obligatoryjne zarówno dla diagnozy - nazwy przedmiotowej, jak i diagnozy - nazwy czynności. Oba znaczenia leksemu diagnoza otwierają po cztery miejsca składniowe, ale właśnie realizacja tego czwartego fakultatywnego miejsca je różnicuje. Diagnoza-nazwa przedmiotowa otwiera miejsce dla środka czynności, na podstawie którego formułuje się diagnozę, a diagnoza-czynność - dla nazwy narzędzia, za pomocą którego przeprowadzane jest diagnozowanie.

\section{diagnoza [za pomocą czegoś]}

Diagnoza oznaczająca czynność otwiera pozycję dla narzędzia. Diagnozy różnego typu wykonuje się często za pomocą specjalistycznych badań (czynności),

13 Jest to test zaproponowany przez Jarmilę Panevovą używany w badaniu pozycji w schematach składniowych, służący do sprawdzenia, które z pozycji są obligatoryjne (za: Danielewiczowa, 2010, s. 13-20). 
czasem za pomocą określonych urządzeń diagnostycznych ${ }^{14}$. Przy realizacji tej pozycji stosuje się konstrukcje za pomoca / przy wykorzystaniu / korzystając / używając + nazwa narzędzia $\mathrm{w}$ dopełniaczu albo przez frazę rzeczownikową w narzędniku, por.

(49) Taką umiejętnością jest np. stawianie diagnozy za pomocą różdżki lub wahadełka. (NKJP, Maria Wolan, Pozornie niewinne $i$ bezpieczne: rzecz o terapiach, medytacjach, wróżbach, zabawach $z$ duchami, 2007)

(50) Dyrektor Kurek ma nadzieję, że pierwsze diagnozy przy wykorzystaniu nowego sprzętu będzie można wykonać jeszcze w tym roku. (NKJP, (bas),Tomograf do końca roku, 2006)

(51) Aby prowadzić diagnozę narzędziem ADOS-2 należy przejść specjalistyczny kurs i uzyskać certyfikat diagnosty ADOS-2 (zwykłą diagnozę może robić każdy psycholog i pedagog). (Szczepan Cieślak, Jak diagnozować autyzm?, 2017)

Pozycja narzędzia przy diagnozie-nazwie czynności najczęściej nie jest realizowana powierzchniowo. Natomiast diagnoza-nazwa przedmiotowa w ogóle nie otwiera pozycji dla narzędzia, ponieważ jest to już efekt diagnozowania (rezultat badania), por.:

(52) Jan przeprowadził diagnozę za pomocą stetoskopu. (czynność)

(53) *Jan postawił diagnozę za pomocą stetoskopu. (rezultat czynności)

\section{diagnoza [na podstawie czegoś]}

Diagnoza oznaczająca rezultat czynność otwiera pozycję dla środka czynności, na podstawie którego postawiono diagnozę. Pozycja te rzadko jest realizowana powierzchniowo, a jeśli się pojawia, jest wprowadzana przez wyrażenie na podstawie + rzeczownik (fraza rzeczownikowa) w dopełniaczu lub przez wyrażenie w oparciu o + rzeczownik (fraza rzeczownikowa) w bierniku, por.:

(54) Lekarz odwiedzający chorego najczęściej jest w stanie postawić diagnozę na podstawie opisanych objawów i badania chorego. (NKJP, Ewa Pakuła, Zapalenie płuc. Leżenie obowiązkowe. Stawianie baniek, 2001)

(55) Pomaga mu konsylium złożone ze współczesnych lekarzy (psychiatra, neurolog, internista i specjalista chorób zakaźnych), którzy stawiają diagnozy w oparciu o znane informacje i przekazy historyczne. („eMPi”, [przeczytane] Stawnych Polaków choroby, 2004)

14 Możliwe jest przeprowadzenie diagnozy (diagnozowania) bez żadnych narzędzi, jedynie na podstawie wiedzy i doświadczenia agensa dokonującego diagnozy, np. Doświadczony weterynarz bez żadnego sprzętu przeprowadził diagnozę psa. 


\section{odbiorca diagnozy}

Słownik Walenty notuje schematy wskazujące na odbiorcę diagnozy (por. zdania (25) i (26)). W NKJP pojawia się więcej takich przykładów, por.:

(56) Dyrekcja postanowiła zorganizować w tym dniu także diagnozy dla gimnazjalistów z klas drugich i pierwszych. (NKJP, MIG, Próba wiedzy, 2003)

(57) Ponieważ Czarodziej należał do grupy mądrych i elastycznych menedżerów, zaczął od postawienia diagnozy dla swego zespołu. (NKJP,Ewa Hurhal, Jak Czarodziej-Menedżer zarządzat swoimi krasnoludkami-agentami cz. 1, 2002)

Pojawiająca się w przykładach realizacja z użyciem konstrukcji z przyimkiem dla, jest moim zdaniem niepoprawna (u autorów słownika walencji Walenty przykłady te nie budzą zastrzeżeń). Być może jest to albo pewien skrót (tak jak w zdaniu (56), gdzie przyimek dla związany jest z czasownikiem zorganizować, a nie rzeczownikiem diagnoza: Dyrekcja postanowiła w tym dniu także zorganizować dla gimnazjalistów $z$ klas drugich $i$ pierwszych diagnozy), albo są to konstrukcje eliptyczne tak jak w zdaniu (57): diagnoza przeznaczona dla. Nie sądzę, aby pozycja odbiorcy diagnozy była obligatoryjna. Być może trzeba by uznać ją za szczególną realizację pozycji obiektu (diagnoza CZEGOŚ), wówczas adresat diagnozy byłby jednocześnie jej obiektem - występowałby niejako w podwójnej roli.

\section{Łączliwość leksemu diagnoza}

\section{/a/ diagnoza w połączeniach $\mathrm{z}$ czasownikami}

Słownik frazeologiczny (1985, s. 170) wskazuje na łączliwość leksemu diagnoza z czasownikami stawiać, postawić. Przegląd przykładów w NKJP pokazuje, że diagnoza występuje $\mathrm{z}$ różnymi czasownikami zarówno $\mathrm{w}$ pozycji podmiotu, jak i w pozycji dopełnienia. Różnice w łączliwości są związane ze znaczeniem leksemu diagnoza.

1) diagnoza-czynność

a. w pozycji mianownikowej:

i. [diagnoza w M.] była / została przeprowadzona / wykonana / zapewniona / dokonana [przez KOGOŚ - agensa]

b. w pozycji dopełnienia

i. [KTOŚ - agens] przeprowadził / przeprowadzał / prowadził / wykonał / wykonywał / zapewniał / zapewnił / zadbał o [diagnoza w B.],

ii. [KTOŚ - agens] dokonał / dokonywał [diagnoza w D.],

iii. [KTOŚ - obiekt] poddał się [diagnoza w C.], 
iv. [KTOŚ - obiekt] przeszedł [diagnoza w B.];

2) diagnoza-nazwa przedmiotowa

a. w pozycji dopełnienia:

i. [KTOŚ - agens] postawił / opracował / sformułował / przedstawił / wywiódł / ustalił / wydał / przesłał /zakomunikował / wygłosił / potwierdził / wykluczył / rozpatrywał / pokusić się o [diagnoza w B.];

ii. [KTOŚ - adresat] czekał na / dostał / usłyszał / miał / znał / zignorował [diagnoza w B.],

iii. [KTOŚ - adresat] wystraszył się / bał się [diagnoza w D.],

iv. [KTOŚ - adresat] zaufał [diagnoza w C.].

\section{/b/ diagnoza jako nadrzędny człon grupy rzeczownikowej}

W przypadku diagnozy-nazwy czynności określenia wskazują najczęściej na przebieg diagnozy lub sposób przeprowadzenia badań (bezinwazyjna, por. (61)). Natomiast przydawki przy diagnozie-nazwie przedmiotowej służą jej wyodrębnieniu (np. każda, taka) lub ocenie (pozytywnej np. trafna, celna, por. (58)-(59) albo negatywnej np. błędna, por. (60)). Najczęściej wyrażane są formą przymiotnika, por.:

(58) Jedna celna diagnoza i wpędzisz mnie w kompleksy. (NKJP, Artur Baniewicz, Drzymalski przeciw Rzeczpospolitej, 2004)

(59) W normalnym przypadku byłaby to trafna diagnoza, ale to nie jest normalny przypadek. (NKJP, Robert A. Heinlein, Obcy w obcym kraju, 2008)

(60) To błędna diagnoza. Nie zgadzam się z twierdzeniem, że w Polsce nie było dobrego gruntu dla soborowych inspiracji i zmian (NKJP, Jarosław Makowski, Kobiety ucza kościót, 2007)

(61) Nowoczesne aparaty USG i radiologiczny pozwolą na lepsze i szybsze diagnozowanie chorób nowotworowych, a przy tym zapewnią bezinwazyjną diagnozę przy wielu innych schorzeniach. (źródło NKJP, Iwona Kuźnia, Diagnoza na miejscu, 2001)

W obu znaczeniach leksemu diagnoza mogą pojawić się przydawki typu medyczna / psychologiczna / biologiczna itd., por.:

(62) Idealnym przykładem są wspomniane programy, które znajdują mikropęknięcia w rurze albo wspomagają diagnozę medyczną. (NKJP, Edward Nęcka, Człowiek - umyst - maszyna: rozmowy o twórczości i inteligencji, 2005)

(63) Najpierw przeprowadzamy pełną diagnozę pedagogiczną i psychologiczną, prosimy o przyniesienie ze sobą zeszytów i klasówek. (NKJP, Jacek Sypień, Co $z$ tą dysleksją?, 2005) 
(64) Zachęceni poprzednimi sukcesami - podczas ubiegłorocznej akcji, w której brało udział ponad 800 specjalistów, przyjęto ponad 5000 osób, diagnozę logopedyczną przeprowadzono u noworodków, dzieci jak i dorosłych. (NKJP, Magdalena Kiliszek, Listy, 2004)

Takie określenie diagnozy jest związane z dziedziną lub (sub)dyscypliną naukową, której ona dotyczy, por.:

(65) *Jan postawiał diagnozę psychologiczną, choć nie dotyczyła ona psychologii.

Z tej przynależności do danej dziedziny / dyscypliny naukowej zdają sprawę słownikowe kwalifikatory, zarówno wtedy, gdy określane nimi rodzaje diagnozy są definiowane jako odrębne znaczenia rzeczownika (np. w WSJP), jak i wtedy, gdy są opisywane jako jej podtypy (np. w USJP).

\section{/c/ diagnoza jako podrzędny człon grupy rzeczownikowej}

Określenia diagnozy mogą też być realizowane przez rzeczownikową transformę odprzymiotnikową (efekt nominalizacji frazy z przymiotnikiem). Wtedy formalnie leksem diagnoza jest podrzędny w stosunku do odprzymiotnikowego derywatu, por.

(66) Wszystko zdawało się potwierdzać trafność diagnozy. (NKJP, Tadeusz Dołęga Mostowicz, Profesor Wilczur, 1990)

(67) Przede wszystkim potwierdza ona, i to w sposób jak najbardziej spontaniczny, przez to właśnie cenny, słuszność diagnozy stawianej przez autora. (NKJP, Kazimierz Wyka, Rzecz wyobraźni, 1959)

Jako podrzędnik w grupie rzeczownikowej diagnoza może również sama określać. Jest wówczas konotowana przez nadrzędnik grupy, por.

(68) O godz. 10.00 szkoła zaprasza na prezentację sprzętu do diagnozy i terapii oraz przesiewowych badań wzroku, słuchu i mowy. (WSJP)

(69) Osoby cierpiące na parkinsonizm mają zagwarantowane prawo do diagnozy i leczenia w placówkach specjalistycznych (Karta praw chorego z chorobą Parkinsona podpisana przez ministra zdrowia w 1998 roku). (NKJP, Anna Krygowska, Choroba Parkinsona, 2003)

\section{Podsumowanie}

Słowniki języka polskiego opatrują hasło diagnoza różnymi kwalifikatorami (biol., med., psych., społ., przen.), sugerując różne znaczenia tego leksemu. Uważam, że analiza pozycji semantyczno-składniowych pozwala na stwierdzenie, że tak naprawdę jest to wskazanie nie różnych znaczeń, lecz podtypów diagnozy 
związanych z różnymi dziedzinami / dyscyplinami naukowymi. Za prymarną można zapewne uznać diagnozę medyczną (opisywany leksem został zapożyczony z języka francuskiego właśnie jako termin medyczny). Z czasem powstały kolejne typy diagnozy wyróżniane ${ }^{15}$ przez słownikarzy (diagnoza biologiczna, psychologiczna, społeczna, pedagogiczna).

W poszczególnych rodzajach odmienne są cele i sposoby dochodzenia do diagnozy, jednakże, moim zdaniem, to za mało, by postulować wieloznaczność leksemu diagnoza. Różnica tkwi bowiem nie w znaczeniu, a w ograniczeniach nakładanych na poszczególne pozycje składniowe. W pozycji CZYJAŚ (X-a) pojawia się osobowy agens (autor) dokonujący diagnozy. W pozycji CZEGOŚ (stanu Y-a / K) pojawia się obiekt diagnozy, oznaczający różne stany czegoś lub sytuacje w zależności od rodzaju diagnozy (np. diagnoza stanu zdrowia, położenia stolicy / przyszłości Ziemi / sytuacji gospodarczej / gatunku). Czasem są to ograniczenia daleko idące, jak w przypadku diagnozy biologicznej, która dotyczy systematyzacji roślin lub zwierzą ${ }^{16}$. Z kolei obligatoryjność treści diagnozy $(\mathbf{p})$ wynika $\mathrm{z}$ fak$\mathrm{tu}$, że diagnoza wymaga przeprowadzenia pewnych operacji mentalnych ${ }^{17}$. Sądzę, że na podstawie zaobserwowanych różnic semantyczno-składniowych można wysunąć hipotezę o funkcjonowaniu leksemu diagnoza w dwóch znaczeniach:

\section{1. diagnoza-nazwa czynności}

\section{CZYJAŚ (X-a) diagnoza CZEGOŚ (stanu Y-a / K) (̇̇e) p [za pomocą f]}

\section{2. diagnoza-nazwa przedmiotowa (nazwa rezultatu czynności)}

\section{CZYJAŚ (X-a) diagnoza \\ CZEGOŚ (stanu Y-a / K) (̇̇e) p [na podstawie g]}

$\mathbf{X}$ - agens osobowy dokonujący diagnozy, realizacja: lewostronnie zaimek lub przymiotnik dzierżawczy, prawostronnie rzeczownik w $\mathrm{D}$.,

Y - obiekt diagnozy, najczęściej nazywający istotę żywą lub przedmiot rzeczownik w D, również pytanie zależne lub konstrukcje typu w sprawie / kwestii / zakresie / dziedzinie + rzeczownik (fraza rzeczownikowa) w D.

15 Lub nie uwzględnione przez słowniki, np. diagnoza logopedyczna, która jako termin specjalistyczny funkcjonuje od dawna (por. Czaplewska, Milewski, 2012, s. 7: „zbiór określonych zasad i metod postępowania badawczego mających na celu ocenę rozwoju mowy osoby badanej oraz określenie nieprawidłowości występujących w procesie komunikowania się").

16 Łączliwość jest w tym wypadku bardzo ograniczona - najczęściej w pozycji dopełniacza pojawia się leksem gatunek lub nazwa rośliny / zwierzęcia. Być może zatem trzeba by uznać diagnozę biologiczną za osobną jednostkę leksykalną, należąca do terminologii biologicznej.

17 Podobnie jak przy agensie i obiekcie diagnozy treść diagnozy (p) jest różna w zależności od jej rodzaju (np. [diagnoza]: astma oskrzelowa / że mam pęknięty kolektor). 
$\mathbf{K}$ - obiekt diagnozy, realizacja: nazywający zdarzenie rzeczownik w D. nazywający zdarzenie, pytanie zależne lub konstrukcje typu w sprawie / kwestii / zakresie / dziedzinie + rzeczownik (fraza rzeczownikowa) w D.

p - treść diagnozy, realizacja: że_/ pytanie zależne / cytat / rzeczownik w D.

f - narzędzie diagnozy, realizacja: konstrukcje typu za pomoca / przy wykorzystaniu + nazwa narzędzia w D. / fraza rzeczownikowa w N.

g - środek czynności diagnozy, realizacja: konstrukcje typu na podstawie + nazwa środka czynności w D. / w oparciu o + nazwa środka czynności w B.

Na koniec chciałabym jeszcze raz zwrócić uwagę na trudności w interpretacji powierzchniowych realizacji schematu. Diagnoza zawsze jest czyjaś, dotyczy czegoś i zawiera jakąś treść. Przy diagnozie-czynności może być realizowana (jest dla niej miejsce) pozycja dla narzędzia, zaś przy diagnozie-nazwie przedmiotowej - pozycja dla środka czynności. Przegląd przykładowych wypowiedzi pokazuje, że rzadko wszystkie pozycje wskazane realizowane są powierzchniowo. A to mimo wszystko nie zawsze pozwala na jednoznaczną interpretację wypowiedzi, ponieważ pojawiający się prawostronnie przy rzeczowniku diagnoza dopełniacz może odpowiadać trzem różnym pozycjom w modelu walencji: agensa, obiektu i treści.

\section{Bibliografia}

Bańkowski, A. (2000). Etymologiczny słownik języka polskiego. Warszawa: PWN.

Buttler, D. (1976). Innowacje składniowe współczesnej polszczyzny (walencja wyrazów). Warszawa: PWN.

Czaplewska, E., Milewski, S. (red.). (2012). Diagnoza logopedyczna. Podręcznik akademicki. Sopot: Gdańskie Wydawnictwo Psychologiczne.

Danielewiczowa, M. (2010). Schematy składniowe - podstawowe kwestie metodologiczne, Poradnik Językowy, 3, 5-27.

ISJP - Inny słownik języka polskiego, Bańko, M. (red.). Warszawa: PWN, 2000.

SFraz. - Słownik frazeologiczny języka polskiego, Skorupka, S. (red.). Warszawa: Wydawnictwo Wiedza Powszechna, 1985.

SJPD - Słownik języka polskiego, Doroszewski, W. (red.). Warszawa: PWN, 1958-1969.

SWB - Słownik wyrazów bliskoznacznych, Ludwiczak, D., Piskadłowa, A., Tarka-Huczek, E. (red.). Warszawa: Wydawnictwo Wiedza Powszechna, 1998.

USJP - Uniwersalny słownik języka polskiego, Dubisz, S. (red.). Warszawa: PWN, 2003.

Zaron, Z. (2012). Wybrane problemy składni funkcjonalnej. Warszawa: BEL Studio, Wydział Polonistyki Uniwersytetu Warszawskiego. 
ABSTRAKT: Celem analizy jest zaprezentowanie walencji rzeczownika diagnoza. Przegląd definicji słowikowych ma pomóc w ustaleniu, ile znaczeń diagnozy powinno się wyróżniać. Na podstawie analizy przykładów słownikowych i schematów ze słownika walencji Walenty przedstawiona została struktura omawianego leksemu. Wypowiedzi z NKJP służą do scharakteryzowania pod względem morfologicznym i semantycznym pozycji, które diagnoza otwiera. W podsumowaniu wskazuję trudności w interpretacji powierzchniowych realizacji schematu tego rzeczownika. 